\title{
Rice koji reduced body weight gain, fat accumulation, and blood glucose level in high-fat diet-induced obese mice
}

Rice koji is considered a readily accessible functional food that may have health-promoting effects. We investigated whether white, yellow, and red koji have the anti-obesity effect in C57BL/6J mice fed a high-fat diet (HFD), which is a model for obesity. Mice were fed HFD containing $10 \%(\mathrm{w} / \mathrm{w})$ of rice koji powder or steamed rice for 4 weeks. Weight gain, epididymal white adipose tissue, and total adipose tissue weight were significantly lower in all rice koji groups than in the HFD-rice group after 4 weeks. Feed efficiency was significantly reduced in the yellow koji group. Blood glucose levels were significantly lower in the white and red koji groups with HOMA-R and leptin levels being reduced in the white koji group. White and red koji increased glucose uptake and GLUT4 protein expression in L6 myotube cells. These results showed that all rice koji have the anti-obesity or anti-diabetes effects although the mechanisms may differ depending on the type of rice koji consumed. 
1 Yumiko Yoshizaki ${ }^{1}$, Chihiro Kawasaki ${ }^{1}$, Kai-Chun Cheng ${ }^{2}$, Miharu Ushikai ${ }^{2}$, Haruka Amitani ${ }^{2}$,

2 Akihiro Asakawa ${ }^{2}$, Kayu Okutsu ${ }^{1}$, Yoshihiro Sameshima ${ }^{1}$, Kazunori Takamine ${ }^{1}$, Akio Inui ${ }^{2 *}$

$3{ }^{1}$ Division of Shochu Fermentation Technology, Education and Research Center for Fermentation

4 Studies, Faculty of Agriculture, Kagoshima University, Kagoshima City, Japan

5 2Department of Social and Behavioral Medicine, Kagoshima University Graduate School of

6 Medical and Dental Sciences, Kagoshima City, Japan

7 * Corresponding author

8 Akio Inui

9 Department of Social and Behavioral Medicine, Kagoshima University Graduate School of

10 Medical and Dental Sciences, 8-35-1 Sakuragaoka, Kagoshima City 890-8520, Japan

11 Tel/fax: +81-99-275-5751

12 E-mail address: inui@m.kufm.kagoshima-u.ac.jp 
Obesity, which is characterized by an increase in fat mass and body weight, results from a combination of excessive food intake and a lack of physical activity (Carek \& Dickerson, 1999). Obesity is a problem in many developed countries because it is often associated with many additional health problems: cancer, hypertension, neurological disorders, and cardiovascular diseases (Spiegelman \& Flier, 2001; Formiguera \& Cantón, 2004; Steinbaum, 2004). The type 2 diabetes is also one of the illnesses related to obesity. The prevalence and incidence of type 2 diabetes are dramatically increasing worldwide in both developed and developing countries. This disease results from the interaction of genetic predispositions such as defective $\beta$-cell function and environmental factors such as insulin resistance, which is influenced by lifestyle and the degree of physical activity. Because obesity increases the risk of illness and premature mortality (Barlow et al., 1995; Hu et al., 2001), the prevention or abatement of obesity is important.

Dietary modifications, exercise, behavioral treatment, and drug therapy have been shown to be helpful for treating obesity (Dulloo et al., 1999). Currently, interest in safer diet treatments is increasing, and the trend of consumer preferences for natural foods has been observed (Leonard et al., 2002). Japan has many traditional fermented foods such as sake, miso, soy sauce, and shochu. These products have attracted worldwide attention as foods that might promote longevity because of their superior antioxidant properties and functional nutrients compared to non-fermented ingredients (Murooka \& Yamashita, 2008).

$K o j i$, which is a solid-state culture of koji molds on cereal grains such as rice and barley, is the commonly used material in these products. Because koji mold produces many types of enzymes and secretes them as it grows, koji is important for the digestion of plant materials like starch, protein, and lipid during the manufacture of fermented foods. These enzymes not only are useful for fermentation but also contribute to the enhancement of the functional nutrient content of fermented products (Koseki et al., 1998). Furthermore, it has also been confirmed that koji mold produce the secondary metabolite as functional compounds such as kojic acid and pyranonigrin-A (Miyake et al., 2008; Choi et al., 2012).

$K o j i$ is used often to prepare fermented foods in eastern-Asian countries. Yellow koji mold (Aspergillus oryzae) and white koji mold (Aspergillus kawachii) have been used in Japan. Yellow koji mold has been used in sake, soy source, and miso, whereas white koji mold were used exclusively in the manufacture of shochu. Red koji mold (Monascus spp.) has been used as the source of fermented foods in China, Japan, Taiwan, and Indonesia. Red koji mold is well known as the fungus that produces a variety of functional chemical compounds such as monacolin $\mathrm{K}$ and $\gamma$-aminobutyric acid (GABA) (Su et al., 2003). Although fermented foods have been well studied, the different effects of various types of koji have not been reported.

We hypothesize that rice koji has antiobesity effects because the compounds from koji are presumably responsible for part of the functions of fermented foods (Yamada et al., 1998). Thus, the objective of this study was to evaluate the antiobesity activity of various types of rice $k o j i$ in an animal model with high-fat diet (HFD)-induced obesity and to elucidate the effect of glucose homeostasis. 


\section{Animals and cell line}

CE-2 as a normal diet and HFD composed of $60 \%$ of calories from lipids were purchased from CLEA Japan, Inc. (Tokyo, Japan) and Research Diets Inc. (New Brunswick, NJ, USA), respectively. Male C57BL/6 mice were purchased from CLEA Japan, Inc. at 7 weeks of age. After arrival, each mouse was housed in an individual cage and maintained on a 12-h/12-h light-dark cycle in a temperature-controlled room $\left(22 \pm 2{ }^{\circ} \mathrm{C}, 50 \% \pm 10 \%\right.$ humidity). The mice were allowed free access to water and a normal diet for acclimatization ( 1 week). After acclimatization, the mice were divided into 5 body weight-matched groups $(\mathrm{n}=12$ per group) as follows. Group-I (CE-rice) was fed CE-2; Group-II (HFD-rice), a HFD containing 10\% (w/w) steamed rice powder; Group-III (HFD-Y), a HFD containing 10\% (w/w) yellow koji powder; Group-IV (HFD-W), a HFD containing 10\% (w/w) white koji powder; and Group-V (HFD-R), a HFD containing $10 \%(\mathrm{w} / \mathrm{w})$ red koji powder. Body weight and food intake were measured every week. This study was approved by the ethical committee for animal experimentation at Kagoshima university graduate school of medical and dental sciences (Permit Number: MD10122). The L6 rat skeletal muscle cell line was obtained from American Type Culture Collection Inc. (ATCC) (Rockville, MD, USA).

\section{Preparation of rice $k o j i$}

All rice koji were prepared in our laboratory. The seed cultures of Aspergillus oryzae and Aspergillus kawachii were purchased from Kawauchi Genichiro shoten (Kagoshima, Japan). The seed culture of Monascus anka was purchased from Akita Konno Co., Ltd. (Akita, Japan). Solidstate fermentation was performed to prepare koji as described in our previous paper (Yoshizaki, et al., 2010a; Yoshizaki, et al., 2010b). The koji preparation was freeze-dried, ground to powder, and stored at $-80^{\circ} \mathrm{C}$ until use.

\section{Analysis of nutrient components}

Moisture, protein, fat, ash, carbohydrate, and energy were analyzed by Japan Food Research Laboratories (Tokyo, Japan). Moisture and protein were measured by heating-drying method and Kjeldahl method, respectively. Fat and ash were measured gravimetrically after the extraction and the incineration, respectively. Carbohydrate was calculated by subtracting the amount of moisture, protein, fat, and ash from 100 . The energy values were calculated by means of Atwater's factors (protein and carbohydrate $4 \mathrm{kcal} / \mathrm{g}$ and fat $9 \mathrm{kcal} / \mathrm{g}$, respectively). Glucose was measured according to the method described in our previous study (Okutsu et al., 2012). High-performance liquid chromatography (HPLC) consisted of a COSMOSIL Sugar-D column (i.d., $4.6 \times 250 \mathrm{~mm}$; Nacalai Tesque, Inc., Kyoto, Japan) and a refractive index detector (Shimadzu Co., Kyoto, Japan). The mobile phase consisted of $\mathrm{CH}_{3} \mathrm{CN}: \mathrm{H}_{2} \mathrm{O}$ (75:25) at a flow rate of $1.0 \mathrm{ml} / \mathrm{min}$. The column temperature was maintained at $40^{\circ} \mathrm{C}$. Citric acid was analyzed using HPLC consisting of an ion-exclusion column (Shim-pack SCR-102H; i.d., $8 \times 300 \mathrm{~mm} \times 2$; Shimadzu Co.) and post-column $\mathrm{pH}$-buffered electroconductivity detection (Shimadzu Co.). The mobile phase consisted of $4 \mathrm{mM}$ of $p$-toluenesulfonic acid solution at a flow rate of $0.8 \mathrm{ml} / \mathrm{min}$. A reaction mixture of $4 \mathrm{mM} p$-toluenesulfonic acid with $16 \mathrm{mM}$ bis-tris and $80 \mu \mathrm{M}$ ethylenediaminetetraacetic acid disodium salt (EDTA) was used as post-column reagent at a flow rate of $0.8 \mathrm{ml} / \mathrm{min}$. The column temperature was maintained at $50^{\circ} \mathrm{C}$.

\section{Blood sample analysis and isolation of tissue material}

After 4 weeks of feeding on the respective diets, mice were fasted for $4 \mathrm{~h}$. Then, blood samples were obtained from the orbital sinus under diethyl ether anesthesia at the end of the 
experiment. Mice were euthanized by cervical dislocation. Immediately after, liver, visceral white adipose tissue, epididymal white adipose tissue, and brown adipose tissue tissue were removed and weighed. The entire sampling procedure was done in less than 2 min. Blood samples were collected and immediately centrifuged at $1,500 \times \mathrm{g}$ for $10 \mathrm{~min}$ at $4^{\circ} \mathrm{C}$. The serum was sampled and stored at $-80^{\circ} \mathrm{C}$ until analysis. Concentrations of total cholesterol (TC), high-density lipoprotein (HDL) cholesterol, triglyceride (TG), and glucose were measured using a clinical chemistry reagent kit (Cholesterol E test, HDL-Cholesterol test, and Triglyceride G test; Wako Pure Chemical Industries, Ltd., Osaka, Japan). Blood glucose was measured with the Nipro Freestyle Freedom (Nipro Co., Osaka, Japan). Concentrations of insulin and leptin were measured using an enzyme immunoassay (Mouse Insulin kit and Mouse leptin kit; Morinaga Institute of Biological Science, Inc., Yokohama, Japan). The adiponectin concentration was evaluated by a sandwich ELISA system (Mouse/Rat adiponectin ELISA kit; Otsuka Pharmaceutical Co. Ltd., Tokyo, Japan). Homeostasis model assessment of insulin resistance $($ HOMA-R) was calculated as (fasting glucose level $(\mathrm{mg} / \mathrm{dl}) \times$ fasting insulin level $(\mathrm{ng} / \mathrm{ml})) / 450$.

\section{Total RNA isolation and real-time PCR}

Total RNA in the liver was prepared from frozen tissue using the NucleoSpin RNA II kit (Macherey-Nagel Ltd., Düren, Germany). The cDNA was synthesized from $1 \mu \mathrm{g}$ of total RNA with the Prime Script RT reagent kit (Takara Bio Inc., Tokyo, Japan). Real-time PCR was performed using SYBR Premix ExTaq (Takara Bio Inc.) on a Thermal Cycler Dice real-time system (Takara Bio Inc.) for 40 cycles of $95^{\circ} \mathrm{C}$ for $30 \mathrm{~s}$ and $60^{\circ} \mathrm{C}$ for $30 \mathrm{~s}$. Commercially available, prevalidated primer pairs were purchased from the Perfect Real-time primer Support System (Takara Bio Inc.). $\beta$-Actin (GenBank accession No. NM_007393.3) was used as endogenous control for all target genes. Fatty acid synthase (FAS; GenBank accession No. NM_007988.3), acetyl-coenzyme A carboxylase- $\alpha$ (ACAC $\alpha$; GenBank accession No. NM_NM_133360.2), acetyl-coenzyme A carboxylase- $\beta$ (ACAC $\beta$; GenBank accession No. NM_133904.2), carnitine palmitoyltransferase 2 (Cpt2; GenBank accession No. NM_009949.2), acyl-Coenzyme A dehydrogenase, very long chain (Acadvl; GenBank accession No. NM_017366.3), acyl-Coenzyme A dehydrogenase, long-chain (Acadl; GenBank accession No. NM_007381.4), acyl-Coenzyme A dehydrogenase, medium chain (Acadm; GenBank accession No. NM_007382.5), and peroxisome proliferator-activated receptor- $\alpha$ (PPAR $\alpha$; GenBank accession No. NM_001113418.1) were the target genes. Gene expression results are expressed as the expression ratio relative to $\beta$-actin gene expression, which were determined according to the manufacturer's instructions. Product specificity was verified by melting curve analysis.

\section{Glucose uptake assay in L6 myotube cells}

Steamed rice, white $k o j i$, or red koji powder ( $5 \mathrm{~g}$ ) was added to $25 \mathrm{ml}$ deionized water and homogenized at 11,000 rpm for $1 \mathrm{~min}$. The homogenate was centrifuged at 21,500 $\times \mathrm{g}$ for 10 min, and the supernatant was used as the extract. The extract was diluted in deionized water for use in the assay. The dilution ratios of these extracts are shown in the figures as the dilution factor (DF). Insulin $(0.1 \mu \mathrm{M})$ was used in place of the extract as a positive control.

For the glucose uptake assay, monolayers of L6 myotube cells were grown in DMEM/high glucose medium containing $4.5 \mathrm{~g} / \mathrm{L}$ glucose (HyClone, Thermo Fisher Scientific Inc., Logan, UT) in a humidified $5 \% \mathrm{CO}_{2}$ incubator at $37^{\circ} \mathrm{C}$. Cells $\left(1 \times 10^{5} / \mathrm{ml}\right)$ were seeded in 10 -cm petri dishes and grown to $90 \%$ confluency. The cells were washed 3 times in phosphatebuffered saline (PBS). The culture medium was replaced for $3 \mathrm{~h}$ with DMEM without glucose medium (Invitrogen Co., Carlsbad, CA, USA), and the cells were trypsinized. A centrifugation step was performed to remove trypsin, and the cells were resuspended in DMEM without glucose medium at $2 \times 10^{6} \mathrm{cells} / \mathrm{ml}$. This culture medium $\left(0.5 \mathrm{ml}\right.$ containing $1 \times 10^{6}$ cells $)$ was transferred 
to each test tube, and $0.5 \mathrm{ml}$ DMEM without glucose medium and the extract or insulin solution $(0.1 \mathrm{ml})$ were added to the tube. After preincubation at $37^{\circ} \mathrm{C}$ for $5 \mathrm{~min}, 10 \mu \mathrm{l}$ of $20 \mathrm{mM} \mathrm{2-}(\mathrm{N}-[7-$ nitrobenz-2-oxa-1,3-diazol-4-yl]amino)-2-deoxyglucose (2-NBDG; Invitrogen Co.) was added (Zou et al., 2005). Test tubes were incubated at $37^{\circ} \mathrm{C}$ with $5 \% \mathrm{CO}_{2}$ for $30 \mathrm{~min}$. The 2-NBDG uptake reaction was stopped by removing the incubation medium and washing the cells twice with pre-chilled PBS. Each test tube was subsequently resuspended in $500 \mu 1$ pre-chilled PBS and measured on a fluorescence spectrometer (Hitachi F-2500; Hitachi, Ltd., Tokyo, Japan) with excitation and emission set at 480 and $520 \mathrm{~nm}$, respectively. All data presented were obtained from at least 3 separate cell preparations.

\section{Western blotting analysis}

The koji extract was the same sample as in the glucose uptake assay. Monacolin K, manscin, or citrate-Na buffer ( $\mathrm{pH} 7.4)$ were also prepared to exposure for cells; monacolin $\mathrm{K}$ solutions (1-1000 $\mu \mathrm{M})$, monascin solution $(5-20 \mu \mathrm{M})$, and citrate-Na buffer ( $\mathrm{pH} 7.4)(3-150 \mathrm{mM})$, respectively. Cells $\left(1 \times 10^{5}\right.$ cells $)$ were grown in $10-\mathrm{cm}$ petri dishes with $5 \mathrm{ml} \mathrm{DMEM} / \mathrm{high}$ glucose medium and $0.1 \mathrm{ml}$ samples for $14 \mathrm{~h}$, The L6 myotube cells were washed 3 times in PBS, trypsinized, and the trypsin was removed by centrifugation. Protein extracts were prepared by homogenizing the tissue in $50 \mathrm{mM}$ Tris- $\mathrm{HCl}(\mathrm{pH} \mathrm{7.6)}$ and $0.1 \%$ Triton $\mathrm{X}-100$ supplemented with a protease inhibitor cocktail (F. Hoffmann-La Roche Ltd., Mannheim, Germany) and centrifuged at $21,500 \times g$ for $30 \mathrm{~min}$. The supernatant was used as the crude extract. The protein concentrations of extracts were determined using the Coomassie Protein Assay Reagent Kit (Thermo Fisher Scientific, Inc., CA, USA). Samples containing $60 \mu \mathrm{g}$ of total protein were separated by sodium dodecyl sulfate-polyacrylamide gel electrophoresis (SDS-PAGE) using 10\% gels and transferred to polyvinylidene fluoride (PVDF) membranes (Hybond-P, GE Healthcare UK Ltd., Buckinghamshire, UK). Membranes were probed with glucose transporter type 4 (GLUT4) and $\beta$-actin antibodies. The signal intensities were quantitated using the NIH Image J software (http://rsb.info.nih.gov/nih-image).

\section{Statistical analyses}

Data are expressed as the means \pm SE. Statistical analyses were performed using SPSS software. Analysis of variance (ANOVA) was performed for the comparisons between groups. Significant differences $(P<0.05)$ between means were determined using Dunnett's multiple comparison tests. 
178

179

180

181

182

183

184

185

186

187

188

189

190

191

192

193

194

195

196

197

198

199

200

201

202

203

204

205

206

207

208

209

210

211

212

213

214

215

216

217

218

219

220

221

222

\section{Nutritional components in steamed rice, yellow koji, white $k o j i$, and red $k o j i$}

The nutritional components in the steamed rice, yellow koji, white koji, and red koji added to the HFD were investigated (Table 1). The carbohydrate content was lower in rice koji than in steamed rice, whereas the protein content was higher in rice koji. However, the total energy, fat, and ash were approximately the same among steamed rice, yellow koji, white koji, and red koji. All koji molds produced an abundance of glycolysis enzymes such as glucoamylase and $\alpha$-amylase. Furthermore, white koji mold produced a large amount of citric acid during white koji manufacture. Thus, glucose and citric acid contents were measured. The glucose content in rice $k o j i$ was 1,500-2,000-fold larger than that in steamed rice. The citric content of white koji was dramatically higher than in the other materials. Although yellow koji and red koji also contained much higher citric acid levels than did steamed rice, these values were one-tenth the amount of those found in white koji. Ingredient composition of the diets fed to mice is shown in Table 2.

\section{Food intake and body and tissue weights of mice}

Food intake of CE-rice diet and HFD was measured and expressed gram per day. CErice diet is the powder form and tended to be spilled out as shown in the variability of the amount of food measured (Table 3). The food intake rates for the HFD groups were 2.4-3.1 g per day and the energy intakes did not differ significantly between the HFD groups (Table 3 ).

The body weight increased gradually over the course of the experiment for all diet groups (Table 3). In particular, compared with the CE-rice diet, the HFD caused a significant increase in body weight. In groups receiving HFD, all rice koji significantly suppressed weight gain compared to HFD-rice diet. However, feed efficiency (weight gain/food intake $\times 100$ ) was significantly reduced in the yellow koji group compared to the HFD-rice diet group. Liver weights were similar among all groups (Table 3). It was implied that HFD diet for 4 weeks did not induce the fatty liver. The HFD significantly increased the weights of total white adipose tissue compared with the CE-rice diet (Table 3). Furthermore, compared to HFD-rice diet, all rice koji significantly suppressed the weight of total white adipose tissue and epididymal white adipose tissue, in a manner similar to weight gain.

We performed blood analysis and gene expression profiling for these groups because the feed type-related differences on the mice appeared as the body weight gain after 4 weeks.

\section{Lipid contents, adiponectin, and leptin levels in the serum of mice}

Serum TC, HDL, and TG levels were measured to investigate the effects of rice koji on lipid metabolism (Table 4). After 4 weeks, the HFD had increased TC and HDL levels compared with those in the CE-rice diet group, while the TG level remained unchanged. Red koji was previously reported to reduce the levels of plasma natural lipid and TC (Trimarco et al., 2011). Significant differences were not found in TC, HDL, and TG levels between the HFD diet groups in this experiment. However, red koji showed a tendency to reduce the TG level in serum, consistent with previous studies.

Adiponectin decreases the plasma glucose level and enhances the utilization of fatty acids in muscle (Berg et al., 2002; Nawrocki \& Scherer, 2004). Leptin, which has an antifeeding effect, is secreted from adipocytes in response to the accumulation of lipids in cells (Campfield et $a l .$, 1996). Therefore, the influence of rice koji on the secretion of adiponectin and leptin was investigated (Table 4). Although red koji modestly decreased serum adiponectin, it did not significantly change in the experimental groups. The leptin level increased in the HFD groups; however, compared with the HFD-rice group, white koji significantly suppressed this increase. 
223

224

225

226

227

228

229

230

231

232

233

234

235

236

237

238

239

240

241

242

243

244

245

246

247

248

249

250

251

252

253

254

255

256

257

258

259

260

261

262

263

264

265

266

267

268

\section{Blood glucose and serum insulin levels in the mice}

C57BL/6J mice receiving HFD have exhibited severe obesity, hyperglycemia, and hyperinsulinemia (Harte et al., 1999). Herein, we presumed that glucose metabolism was altered by obesity in mice that fed on a HFD for 4 weeks and we therefore measured the blood glucose and serum insulin levels in all mice. A significant increase in blood glucose levels was observed in HFD-fed mice compared to those fed the CE-rice diet after 4 weeks. However, the blood glucose level was significantly lower in the white and red koji groups than in the HFD-rice group (Table 4). The HFD containing rice koji contained a small amount of glucose, approximately $1.5 \sim 2.0 \%(\mathrm{w} / \mathrm{w})$. Thus, our results showed that white and red koji efficiently suppressed the high blood glucose level induced by HFD. Red-mold-fermented-products have been reported to attenuate the development of diabetes and alleviate hyperglycemia (Shi \& Pan, 2010), and our experiments confirmed this effect of red koji. Although the serum insulin level was not different among the experimental groups, the white and red koji groups tended to have lower insulin levels than those of the other HFD groups. HOMA-R, which was used to assess insulin resistance, was significantly lower in the white koji group than in the HFD-rice group. Although the red koji group showed no significant differences in HOMA-R, it tended to have lower HOMA-R than those of the other HFD groups, being reduced to almost the same level as that of the white koji group.

\section{Expression of the fatty acid metabolism enzymes in mice}

Rice koji presumably affect fat metabolism. To determine the molecules involved in fatty acid metabolism in HFD mice upon rice koji feed, we measured the hepatic gene expression of several genes involved in fatty acid metabolism. Fatty acid synthase (FAS), acetyl-CoA carboxylase $\alpha(\mathrm{ACAC} \alpha)$, acetyl-CoA carboxylase $\beta$ (ACAC $\beta)$, carnitine palmitoyltransferase 2 (Cpt2), acyl-Coenzyme A dehydrogenase, very long chain (Acadvl), acyl-Coenzyme A dehydrogenase, long-chain (Acadl), acyl-Coenzyme A dehydrogenase, medium chain (Acadm) and peroxisome proliferator-activated receptor $\alpha(\operatorname{PPAR} \alpha)$ was investigated herein. In the liver, the expression of FAS, ACAC $\alpha$, Cpt2, Acadvl, Acadl, Acadm and PPAR $\alpha$ genes was not significantly different after 4 weeks of HFD feeding (Fig. 1). While the expression level ACAC $\beta$ in the CE-rice group was significantly higher than the other HFD groups, it was not significantly different between HFD groups.

\section{Effect of white and red koji on glucose uptake and GLUT4 protein expression in L6 myotube cells}

It was reported that red mold-fermented products could delay the increase in the blood glucose levels in rats and that red koji protects against diabetes (Hsieh \& Tai, 2003; Shi \& Pan, 2010). This effect of red koji was also confirmed in this study and that of white koji was first recognized (Table 4). Skeletal muscle is the predominant tissue for insulin-stimulated glucose disposal (Koranyi et al., 1991). Glucose enters the muscle cell primarily by facilitated diffusion by utilizing glucose transporter carrier proteins. GLUT4 is the predominantly expressed glucose transporter isoform in muscle (Shepherd \& Kahn, 1999), and whole body glucose disposal and GLUT4 expression are correlated in healthy subjects (Koranyi et al., 1991). Therefore, the glucose uptake activity and GLUT4 protein expression level were measured in muscle cells to investigate the mechanism by which white and red koji suppresses blood glucose. L6 myotube cells were exposed to various concentrations of white and red koji extracts or steamed rice extract. Treatment of L6 myotube cells with white and red koji resulted in a dose-dependent increase in 2-NBDG uptake, similar to that in insulin-stimulated cells (Fig. 2). We examined the expression of GLUT4 proteins in L6 myotube cells stimulated with white and red koji extracts.

PeerJ reviewing PDF | (v2013:01:261:1:2:NEW 4 Aug 2014) 
269 GLUT4 expression increased by approximately 1.5 and 1.6-fold in L6 myotube cells treated with 270 the extract of white and red koji, respectively, compared with cells treated with steamed rice (Fig. $2713)$.

272 To reveal the key compounds in red and white koji, it was investigated the effect of 273 monacolin K, monascin and citric acid on the induction of GLUT4 protein in L6 myotube cells. 274 Monacolin $\mathrm{K}$ is one of the most important compounds in red koji. Recent study was shown that 275 monascin which is one of yellow pigment produced by Monascus sp. prevents fatty acid 276 accumulation in high-fat diet-fed mice (Hsu et al., 2014). Citric acid is one of most abundant 277 compounds in white koji. The exposure concentration was determined the previous results and 278 citric acid concentration in white koji. Because concentrated citric acid solution is strongly acidic, 279 the damage for cells was expected by low $\mathrm{pH}$. Therefore, in this experiment, we used citrate-Na 280 buffer ( $\mathrm{pH}$ 7.4) for investigating the effect of citrate molecule. Our results showed monacolin K 281 and monascin could induce GLUT4 expression (Fig. 4). Citric acid did not have its effect on L6 282 myotube cells. 
283

284

285

286

287

288

289

290

291

292

293

294

295

296

297

298

299

300

301

302

303

304

305

306

307

308

309

310

311

312

313

314

315

316

317

318

319

320

321

322

323

324

325

326

327

328

329

330

331

\section{Discussion}

We used an HFD-feeding animal model to evaluate and confirm the antiobesity effects of three types of rice koji: white koji, yellow koji, and red koji. All types of rice koji significantly decreased weight gain, epididymal white adipose tissue, and total adipose tissue without affecting food intake. It is known that obesity develops when energy intake exceeds energy expenditure. Feed efficiency was significantly reduced in the yellow koji group compared to the HFD-rice diet group. White and red koji showed also a tendency to reduce food efficiency. Taken together, our results suggest that white, yellow, and red koji have a protective effect on HFD-induced fat accumulation by increasing energy expenditure or inhibiting the absorption of excess fat in the diet. These results supported the hypothesis that the rice koji has the anti-obesity effect, and these effects of each rice koji appear to be triggered by different mechanisms because the different koji types have different propensity for feed efficiency, leptin level, blood glucose, and HOMA-R.

Red koji is reported to exhibit a protective effect on alcoholic liver disease, including fatty liver (Cheng \& Pan, 2011). We have demonstrated herein that rice koji containing red koji protect against diet-induced obesity. Furthermore, white and red koji was effective in reducing blood glucose level compared to the HFD-rice diet. It was confirmed that white and red koji increased 2-NBDG uptake and GLUT4 protein expression in L6 myotube cells. It was also revealed that monacolin $\mathrm{K}$ and monascin induced GLUT4 expression on L6 myotube cells. Therefore these compounds could contribute to the increase of GLUT4 protein and the acceleration of glucose uptake by red koji. Although we faield to show the difference between the experimental groups of GLUT4 expression in gastrocemius muscle tissue of mice (data not shown), it might be difficult to detect the difference without separation of red from white muscle tissue, the former of which contains more GLUT4 protein (Kern et al., 1990)

White koji contains a high amount of citric acid in contrast to yellow and red koji. Citric acid, a natural and dietary chelator found in citrus fruits, is widely used in food products as a preservative. Furthermore, it plays a key role in the TCA cycle, which is part of the metabolic pathway involved in the chemical conversion of carbohydrates, fats, and proteins. It was recently reported that citric acid prevents cataracts and nephropathy in diabetic rats (Nagai et al., 2010); this suggests that the energy flux was improved by the citric acid in white koji. Therefore, we expected that citric acid was one of the key compounds in white koji and examined the effect on the induction of GLUT4 protein in the muscle cells. However it did not have the ability. We will continue to look for the key compounds in white koji except for citric acid, because Aspergillus kawachii which is the koji mold used for white koji preparation do not produce monacolin $\mathrm{K}$ and monascin.

Sake is made from fermented rice, yellow koji, and yeast. Sake cake, which is a residue of sake mash, has also been reported to be effective in lowering cholesterol levels in rats (Ashida et al., 1997). The solid content in sake cake has over $70 \%$ protein content, and more than $90 \%$ of its protein is derived from rice. As sake cake is similar to casein I in its digestive efficiency, the indigestive rice protein changes its form into one that can be easily digested by digestive enzymes. Furthermore, pepsin-digestive sake cake is more effective in increasing fecal lipid levels than sake cake and tends to reduce the serum and liver cholesterol and lipid levels (Ashida et al., 1997). Thus, digested rice protein is more effective than its indigestive form in reducing the intestinal lipid absorption and liver and serum cholesterol levels. All rice koji types contain proteolytic enzymes. Digested rice protein is considered to be one of the common functional compounds in rice koji. Furthermore, it was previously reported that the amino acid composition of plant protein in diets also affects the cholesterol level (Vahouny et al., 1985), and rice koji contains compounds from fungus. These compounds may function together in a coordinated manner although further studies are necessary to elucidate the exact mechanisms.

Rice koji accounts for $7 \%$ of the total calories of the diets used in this study. It may be

PeerJ reviewing PDF | (v2013:01:261:1:2:NEW 4 Aug 2014) 
332 difficult for human beings to consume a comparable level of rice koji. However, in Japan, rice $333 k o j i$ could be consumed in dairy meals in various forms. For example, rice koji-miso is prepared 334 with soy and rice koji in a 1:1 proportion, and people can consume this preparation, such as 335 through miso soup. Amazake is saccharified rice koji prepared by incubating rice koji overnight 336 with water at approximately $55^{\circ} \mathrm{C}$; it is also a traditional Japanese drink. Because of this, rice koji 337 is considered a readily accessible functional food and is gaining attention as a natural source of 338 nutrients and health-promoting compounds.

339 In conclusion, we showed all rice koji had the anti-obesity effect by the mechanisms 340 other than food intake regulation. It may involve feed efficiency but may differ depending on the 341 type of rice koji. White and red koji may improve glucose tolerance by the activation of glucose 342 uptake through the increase of GLUT4 protein expression in the muscle. Rice koji should be 343 considered a readily accessible functional food that may be effective for the prevention or 344 treatment of metabolic syndrome.

\section{Acknowledgment}

347 The authors thank K. Kuwamoto MSc. (Faculty of Agriculture, Kagoshima University) 348 for providing technical assistance. 
350

351

352

353

354

355

356

357

358

359

360

361

362

363

364

365

366

367

368

369

370

371

372

373

374

375

376

377

378

379

380

381

382

383

384

385

386

387

388

389

390

391

392

393

394

395

396

Ashida Y, Saito Y, Kawato A, Suginami K, Imayasu S. 1997. Effects of dietary sake cake on cholesterol metabolism in rats. Nippon Nōgeikagaku Kaishi 71: 137-143.

Barlow CE, Kohl HW, Gibbons LW, Blair SN. 1995. Physical fitness, mortality and obesity. International Journal of Obesity and Related Metabolic Disorders 19: 41-44.

Berg AH, Combs TP, Scherer PE. 2002. ACRP30/adiponectin: an adipokine regulating glucose and lipid metabolism. Trends in Endocrinology and Metabolism 13: 84-89.

Campfield LA, Smith FJ, Burn P. 1996. The OB protein (leptin) pathway--a link between adipose tissue mass and central neural networks. Hormone and Metabolic Research 28: 619-632.

Carek PJ, Dickerson LM. 1999. Current concepts in the pharmacological management of obesity. Drugs 57: 883-904.

Cheng CF, Pan TM. 2011. Protective effect of Monascus-fermented red mold rice against alcoholic liver disease by attenuating oxidative stress and inflammatory response. Journal of Agricultural and Food Chemistry 59: 9950-9957.

Choi H, Kim K, Han J, Jin SH, Lee EK, Shin DW, Lee TR, Lee A-Y, Noh M. 2012. Kojic acid-induced IL-6 production in human keratinocytes plays a role in its anti-melanogenic activity in skin. Journal of Dermatological Science 66: 207-215.

Dulloo AG, Duret C, Rohrer D, Girardier L, Mensi N, Fathi M, Chantre P, Vandermander J. 1999. Efficacy of a green tea extract rich in catechin polyphenols and caffeine in increasing 24-h energy expenditure and fat oxidation in humans. American Journal of Clinical Nutrition 70:1040-1045.

Formiguera X, Cantón A. 2004. Obesity: epidemiology and clinical aspects. Best Practice \& Research in Clinical Gastroenterology 18: 1125-1146.

Harte RA, Kirk EA, Rosenfeld ME, LeBoeuf RC. 1999. Initiation of hyperinsulinemia and hyperleptinemia is diet dependent in C57BL/6 mice. Hormone and Metabolic Research 31: 570-575.

Hsieh PS, Tai YH. 2003. Aqueous extract of Monascus purpureus M9011 prevents and reverses fructose-induced hypertension in rats. Journal of Agricultural and Food Chemistry 51: 3945-3950.

Hsu W-H, Chen T-H, Lee B-H, Hsu Y-W, Pan T-M. 2014. Monascin and ankaflavin act as natural AMPK activators with PPAR $\alpha$ agonist activity to down-resulate nonalcoholic steatohepatitis in high-fat diet-fed C57BL/6 mice. Food and Chemical Toxicology 64: 94103.

Hu FB, Leitzmann MF, Stampfer MJ, Colditz GA, Willett WC, Rimm EB. 2001. Physical activity and television watching in relation to risk for type 2 diabetes mellitus in men. Archives of Internal Medicine 161: 1542-1548.

Kern M, Wells JA, Stephens JM, Elton CW, Friedman JE, Tapscott EB, Pekala PH, Dohm GL. 1990. Insulin responsiveness in skeletal muscle is determined by glucose transporter (Glut4) protein level. Biochemical Journal 270: 397-400.

Koranyi LI, Bourey RE, Vuorinen-Markkola H, Koivisto VA, Mueckler M, Mueckler M, Permutt MA, Yki-Järvinen H. 1991. Level of skeletal muscle glucose transporter protein correlates with insulin-stimulated whole body glucose disposal in man. Diabetologia 34: 763-765.

Koseki T, Furuse S, Iwano K, Matsuzawa H. 1998. Purification and characterization of a feruloylesterase from Aspergillus awamori. Bioscience Biotechnology and Biochemistry 62: 2032-2034.

Leonard SS, Cutler D, Ding M, Vallyathan V, Castranova V, Shi X. 2002. Antioxidant 
426

427

428

429

430

431

432

433

434

435

436

437

438

439

440

441

442 properties of fruit and vegetable juices: more to the story than ascorbic acid. Annals of Clinical and Laboratory Science 32: 193-200.

Miyake Y, Mochizuki M, Ito C, Itoigawa M, Osawa T. 2008. Antioxidative pyranonigrins in rice mold starters and their suppressive effect on the expression of blood adhesion molecules. Bioscience Biotechnology and Biochemistry 72: 1580-1585.

Murooka Y, Yamashita M. 2008. Traditional healthful fermented products of Japan. Journal of Industrial Microbiology \& Biotechnology 35: 791-798.

Nagai R, Nagai M, Shimasaki S, Baynes JW, Fujiwara Y. 2010. Citric acid inhibits development of cataracts, proteinuria and ketosis in streptozotocin (type 1) diabetic rats. Biochemical and Biophysical Research Communications 393: 118-122.

Nawrocki AR, Scherer PE. 2004. The delicate balance between fat and muscle: adipokines in metabolic disease and musculoskeletal inflammation. Current Opinion in Pharmacology 4: 281-289.

Okutsu K, Yoshizaki Y, Takamine K, Tamaki H, Ito K, Sameshima Y. 2012. Development of a heat-processing method for koji to enhance its antioxidant activity. Journal of Bioscience and Bioengineering 113: 349-354.

Shepherd PR, Kahn BB. 1999. Glucose transporters and insulin action--implications for insulin resistance and diabetes mellitus. The New England Journal of Medicine 341: 248-257.

Shi YC, Pan TM. 2010. Anti-diabetic effects of Monascus purpureus NTU 568 fermented products on streptozotocin-induced diabetic rats. Journal of Agricultural and Food Chemistry 58: 7634-7640.

Spiegelman BM, Flier JS. 2001. Obesity and the regulation of energy balance. Cell 104: 531543.

Steinbaum SR. 2004. The metabolic syndrome: an emerging health epidemic in women. Progress in Cardiovascular Diseases 46: 321-336.

Su YC, Wang JJ, Lin TT, Pan TM. 2003. Production of the secondary metabolites $\gamma$ aminobutyric acid and monacolin K by Monascus. Journal of Industrial Microbiology \& Biotechnology 30:41-46.

Trimarco B, Benvenuti C, Rozza F, Cimmino CS, Giudice R, Crispo S. 2011. Clinical evidence of efficacy of red yeast rice and berberine in a large controlled study versus diet. Mediterranean Journal of Nutrition Metabolism 4: 133-139.

Yamada T, Hiratake J, Aikawa M, Suizu T, Saito Y, Kawato A, Suginami K, Oda J. 1998. Cysteine protease inhibitors produced by the industrial koji mold, Aspergillus oryzae O1018. Bioscience Biotechnology and Biochemistry 62: 907-914.

Yoshizaki Y, Susuki T, Takamine K, Tamaki H, Ito K, Sameshima Y. 2010a. Characterization of glucoamylase and $\alpha$-amylase from Monascus anka: enhanced production of $\alpha$-amylase in red koji. Journal of Bioscience and Bioengineering 110: 670-674.

Yoshizaki Y, Yamato H, Takamine K, Tamaki H, Ito K, Sameshima Y. 2010b. Analysis of volatile compounds in shochu koji, sake koji, and steamed rice by gas chromatographymass spectrometry. Journal of Institute of Brewing 116: 49-55.

Vahouny GV, Adamson I, Chalcarz W, Satchithanandam S, Muesing R, Klurfeld DM, Tepper SA, Sanghvi A, Kritchevsky D. 1985. Effects of casein and soy protein on hepatic and serum lipids and lipoprotein lipid distribution in the rats. Atheroschlerosis 56: 127-137.

Zou C, Wang Y, Shen Z. 2005. 2-NBDG as a fluorescent indicator for direct glucose uptake measurement. Journal of Biochemical and Biophysical Methods 64: 207-215. 


\section{Table $\mathbf{1}_{\text {(on next page) }}$}

Nutrient components of steamed rice and rice koji.

${ }^{*} \mathrm{fw}$, fresh weight; **dw, dry weight. 


\begin{tabular}{|c|c|c|c|c|c|c|c|c|}
\hline \multirow[b]{2}{*}{ Component } & \multicolumn{5}{|c|}{$\mathrm{g} / 100 \mathrm{~g} \mathrm{fw} *$} & \multicolumn{2}{|c|}{$\mathrm{g} / 100 \mathrm{~g} \mathrm{dw}^{* *}$} & \multirow[t]{2}{*}{$\begin{array}{c}\text { Energy } \\
\left(\mathrm{kcal} / 100 \mathrm{~g} \mathrm{fw}^{*}\right)\end{array}$} \\
\hline & Moisture & Carbohydrate & Protein & Fat & Ash & Glucose & Citric acid & \\
\hline Steamed rice & 4.1 & 87.5 & 7.1 & 1.0 & 0.3 & 0.1 & 2.9 & 387 \\
\hline Yellow koji & 5.4 & 82.9 & 9.3 & 2.1 & 0.3 & 20.0 & 95.9 & 388 \\
\hline White koji & $8.5 \frac{\text { 음 }}{0}$ & 80.5 & 9.2 & 1.5 & 0.3 & 18.8 & 3306.7 & 372 \\
\hline Red koji & $4.9 \stackrel{\infty}{\supset}$ & 83.4 & 9.6 & 1.8 & 0.3 & 15.0 & 104.0 & 388 \\
\hline
\end{tabular}

components of steamed ricēand rice koji.

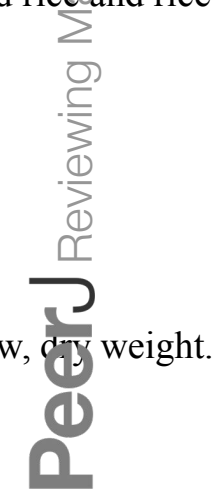




\section{Table 2 (on next page)}

Nutrient components of the diets using in this study.

${ }^{*}$ HFD-rice; high fat diet (HFD) with steamed rice, HFD-Y; HFD with yellow koji, HFD-W; HFD with white koji, HFD-R; HFD with red koji. **fw, fresh weight. 


\begin{tabular}{|c|c|c|c|c|c|}
\hline \multirow[b]{2}{*}{ Diet* } & \multicolumn{3}{|c|}{$\mathrm{g} / 100 \mathrm{~g} \mathrm{fw} * *$} & \multirow{2}{*}{$\begin{array}{c}\text { Energy } \\
\left(\mathrm{kcal} / 100 \mathrm{~g} \mathrm{fw} \mathrm{fw}^{* *}\right)\end{array}$} & \multirow{6}{*}{$\begin{array}{l}\text { Table } 2 . \\
\text { Nutrient } \\
\text { components } \\
\text { of the diets } \\
\text { using in this } \\
\text { study. }\end{array}$} \\
\hline & Carbohydrate & Protein & Fat & & \\
\hline HFD-rice & 32.4 & 24.3 & 32 & 510 & \\
\hline HFD-Y & 31.7 & 24.5 & 32 & 509 & \\
\hline HFD-W & 32.0 & 24.5 & 32 & 510 & \\
\hline HFD-R & 32.0 & 24.5 & 32 & 510 & \\
\hline
\end{tabular}

*HFD-rice; high fat diet (HFD) with steamed rice, HFD-Y; HFD with yellow koji, HFD-W; HFD with white koji, HFD-R; HFD with red koji.

$* * \mathrm{fw}$, fresh weight. 


\section{Table 3 (on next page)}

Body weight, food intake, and tissue weight.

Data are presented as means $\pm S E ; n=12$. Values in a row with different superscripts differ significantly at $P<0.05$ by Dunnett's multiple comparison test (a-c). Feed efficiency was calculated as follow: (weight gain for 4 weeks / food intake for 4 weeks) $\times 100$. 


\begin{tabular}{|c|c|c|c|c|c|c|}
\hline & HFD-rice & HFD-W & HFD-Y & HFD-R & CE-rice & \multirow{10}{*}{$\begin{array}{l}\text { Table 3. Body } \\
\text { weight, fooc } \\
\text { intake, anc } \\
\text { tissue weight. }\end{array}$} \\
\hline Initial body weight (g) & $21.43 \pm 0.35^{\mathrm{a}}$ & $21.35 \pm 0.37^{\mathrm{a}}$ & $21.32 \pm 0.35^{\mathrm{a}}$ & $21.49 \pm 0.32^{\mathrm{a}}$ & $21.30 \pm 0.33^{\mathrm{a}}$ & \\
\hline Food intake (g/day) & $2.94 \pm 0.14^{\mathrm{a}}$ & $2.43 \pm 0.06^{\mathrm{a}}$ & $3.13 \pm 0.18^{\mathrm{a}}$ & $2.77 \pm 0.16^{\mathrm{a}}$ & $6.70 \pm 2.29^{b}$ & \\
\hline Body weight gain (g) & $8.40 \pm 0.43^{\text {a }}$ & $6.60 \pm 0.45^{b}$ & $6.80 \pm 0.36^{\mathrm{b}}$ & $6.74 \pm 0.34^{\mathrm{b}}$ & $3.43 \pm 0.28^{\mathrm{c}}$ & \\
\hline Feed efficiency & $10.36 \pm 0.58^{a}$ & $9.64 \pm 0.50$ ab & $8.10 \pm 0.70^{b}$ & $8.90 \pm 0.53^{\mathrm{ab}}$ & $1.93 \pm 0.18^{\mathrm{c}}$ & \\
\hline Liver weight (g) & $1.14 \pm 0.04^{\mathrm{a}}$ & $1.07 \pm 0.02^{\mathrm{a}}$ & $1.13 \pm 0.03^{\mathrm{a}}$ & $1.11 \pm 0.03^{\mathrm{a}}$ & $1.14 \pm 0.02^{\mathrm{a}}$ & \\
\hline Total white adipose tissue $(\overrightarrow{\mathrm{g}})$ & $1.96 \pm 0.10^{\mathrm{a}}$ & $1.53 \pm 0.15^{b}$ & $1.54 \pm 0.12^{\mathrm{b}}$ & $1.38 \pm 0.10^{\mathrm{b}}$ & $0.53 \pm 0.04^{\mathrm{c}}$ & \\
\hline Visceral white adipose tisswe (g) & $0.60 \pm 0.06^{\mathrm{a}}$ & $0.50 \pm 0.07^{\mathrm{a}}$ & $0.50 \pm 0.07^{\mathrm{a}}$ & $0.43 \pm 0.05^{\mathrm{a}}$ & $0.19 \pm 0.02^{b}$ & \\
\hline Epididymal white adipose 㹘sue (g) & $1.36 \pm 0.08^{\mathrm{a}}$ & $1.04 \pm 0.09^{b}$ & $1.04 \pm 0.07^{\mathrm{b}}$ & $0.95 \pm 0.07^{\mathrm{b}}$ & $0.34 \pm 0.02^{\mathrm{c}}$ & \\
\hline Brown adipose tissue $(\mathrm{g}) \sum_{d}^{3}$ & $0.11 \pm 0.01^{\mathrm{a}}$ & $0.08 \pm 0.01^{\mathrm{a}}$ & $0.10 \pm 0.01^{\mathrm{a}}$ & $0.10 \pm 0.01^{\mathrm{a}}$ & $0.08 \pm 0.02^{\mathrm{a}}$ & \\
\hline
\end{tabular}

Data are presented as matns $\pm \mathrm{SE} ; \mathrm{n}=12$. Values in a row with different superscripts differ significantly at $P<0.05$ by Dunnett's multiple comparison test (a-c). Fee fefficiency was calculated as follow: (weight gain for 4 weeks / food intake for 4 weeks) $\times 100$. 


\title{
Table 4(on next page)
}

Serum lipid, adiponectin, leptin, blood glucose, and insulin levels.

\begin{abstract}
Values in a row with different superscripts differ significantly at $P<0.05$ by Dunnett's multiple comparison test (a-c). Data are presented as mean $\pm S E ; n=9-12$.
\end{abstract}




\begin{tabular}{|c|c|c|c|c|c|c|}
\hline & HFD-rice & HFD-W & HFD-Y & HFD-R & CE-rice & \multirow{8}{*}{$\begin{array}{l}\text { Table 4. Serum } \\
\text { lipid, } \\
\text { adiponectin, } \\
\text { leptin, blood } \\
\text { glucose, and } \\
\text { insulin levels. }\end{array}$} \\
\hline $\mathrm{TC}(\mathrm{mg} / \mathrm{dl})$ & $121.44 \pm 6.60^{\mathrm{a}}$ & $125.84 \pm 4.24^{\mathrm{a}}$ & $123.13 \pm 3.96^{\mathrm{a}}$ & $122.83 \pm 6.90^{\mathrm{a}}$ & $62.36 \pm 2.77^{b}$ & \\
\hline $\mathrm{HDL}(\mathrm{mg} / \mathrm{dl})$ & $83.99 \pm 4.03^{\mathrm{a}}$ & $88.94 \pm 4.85^{\mathrm{a}}$ & $82.10 \pm 5.38^{\mathrm{a}}$ & $82.95 \pm 3.48^{\mathrm{a}}$ & $49.02 \pm 2.52^{b}$ & \\
\hline $\mathrm{TG}(\mathrm{mg} / \mathrm{dl})$ & $81.74 \pm 7.20^{\mathrm{a}}$ & $87.72 \pm 8.99^{\mathrm{a}}$ & $87.16 \pm 7.84^{\mathrm{a}}$ & $72.10 \pm 12.70^{\mathrm{a}}$ & $97.91 \pm 8.60^{\mathrm{a}}$ & \\
\hline Adiponectin $(\mu \mathrm{g} / \mathrm{ml})$ & $16.77 \pm 1.68^{a}$ & $16.04 \pm 0.30^{\mathrm{a}}$ & $15.91 \pm 0.77^{\mathrm{a}}$ & $15.28 \pm 1.00^{\mathrm{a}}$ & $15.54 \pm 1.17^{\mathrm{a}}$ & \\
\hline Leptin $(\mathrm{ng} / \mathrm{mL})$ & 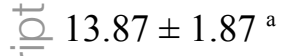 & $8.19 \pm 1.73^{b}$ & $9.17 \pm 2.46^{\mathrm{ab}}$ & $10.47 \pm 1.65^{\mathrm{ab}}$ & $0.88 \pm 0.13^{c}$ & \\
\hline Blood glucose $(\mathrm{mg} / \mathrm{dl})$ & $198.92 \pm 5.24^{a}$ & $178.50 \pm 5.39^{b}$ & $198.25 \pm 5.03^{\mathrm{a}}$ & $176.67 \pm 3.16^{b}$ & $147.25 \pm 7.25^{\mathrm{c}}$ & \\
\hline Insulin $(\mathrm{ng} / \mathrm{ml})$ & $\stackrel{\text { क }}{\supset} 1.32 \pm 0.10^{\mathrm{a}}$ & $1.02 \pm 0.09^{\mathrm{a}}$ & $1.12 \pm 0.16^{\mathrm{a}}$ & $0.92 \pm 0.18^{\mathrm{a}}$ & $0.40 \pm 0.07^{\mathrm{b}}$ & \\
\hline
\end{tabular}

alues in a row with diffe

$\mathrm{SE} ; \mathrm{n}=9-12$. 


\section{Figure 1}

Expression of fat metabolism-related genes in mice fed experimental foods.

Expression of fat metabolism-related genes in liver of mice fed experimental foods. Gene expression level of fatty acid synthase (FAS), Acetyl coenzyme A carboxylase $\alpha$ (ACAC $\alpha$ ), acetyl coenzyme A carboxylase $\beta$ (ACAC $\beta$ ), carnitine palmitoyltransferase 2 (Cpt2), acylcoenzyme A dehydrogenase, very long chain (Acadvl), acyl-coenzyme A dehydrogenase, long-chain (Acadl), acyl-coenzyme A dehydrogenase, medium chain (Acadm), peroxisome proliferator-activated receptor- $\alpha$ (PPAR $\alpha)$ were analyzed by real-rime PCR. Data are expressed as the mean $\pm S E(n=9)$. Dunnett's test was used for multiple comparisons between individual groups $\left({ }^{*} P<0.05\right)$. HFD-rice (black bar), HFD-W (white bar), HFD-Y (light gray bar), HFD-R (gray bar), and CE-rice (dark gray bar).

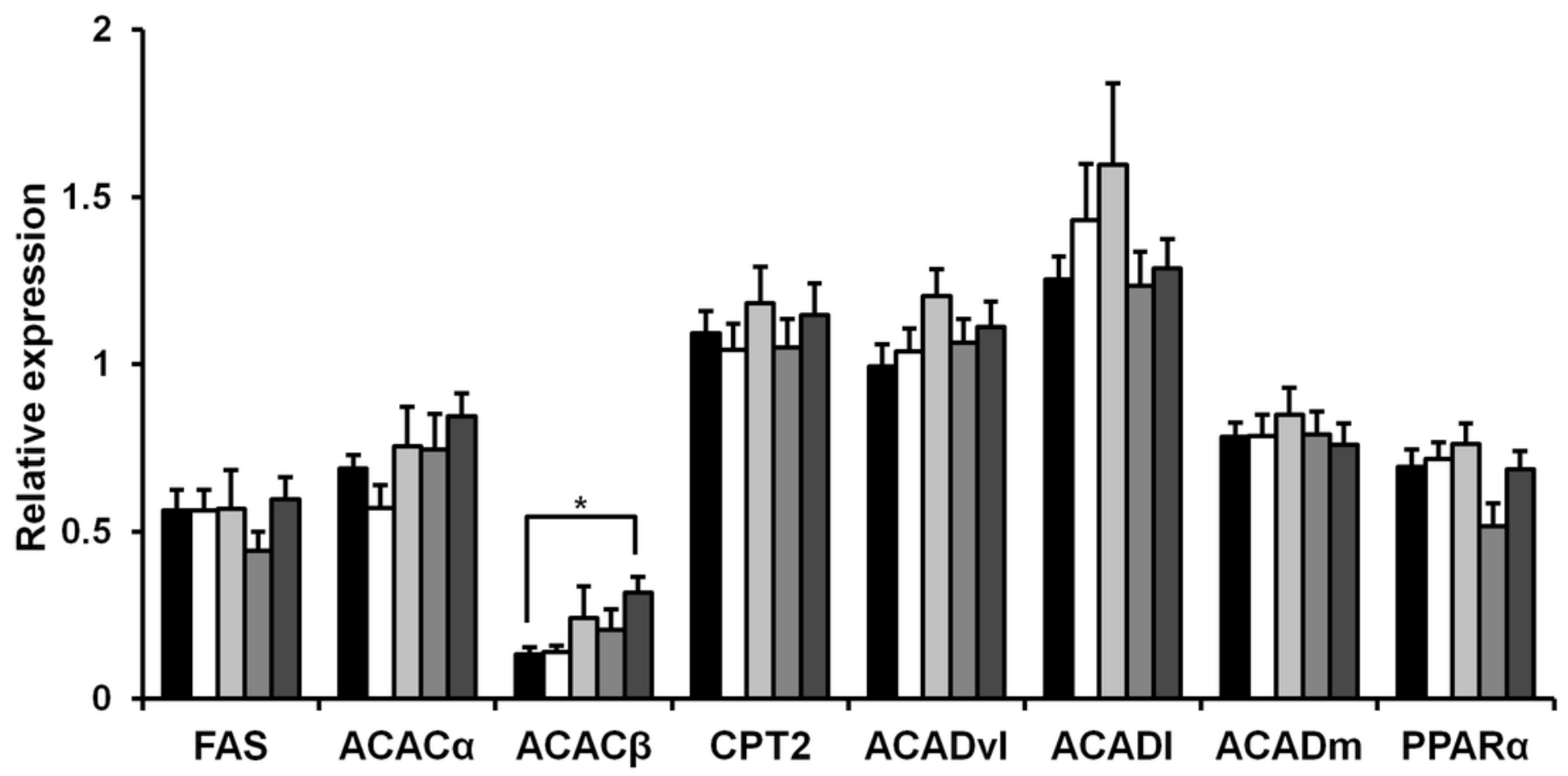




\section{Figure 2}

Dose-dependent analysis of 2-NBDG uptake by white and red koji extracts.

L6 myotube cells were incubated with steamed rice, white koji and red koji extracts at each of the indicated dilutions for $5 \mathrm{~min}$. Each extract was prepared as described in Methods and Materials. Control indicates the L6 myotube cell treated by deionized water instead of the extract. The extract was diluted in deionized water and the dilution ratio of the extract is indicated by the dilution factor (DF). Insulin $(0.1 \mu \mathrm{M})$ was used in place of the extract as a positive control. The 2-NBDG compound was added for $30 \mathrm{~min}$ and uptake was measured. Data are expressed as means $\pm S E(n=12)$. Different letters above the bars were significantly different at $P<0.05$ by Dunnett's multiple comparison (a-d). 


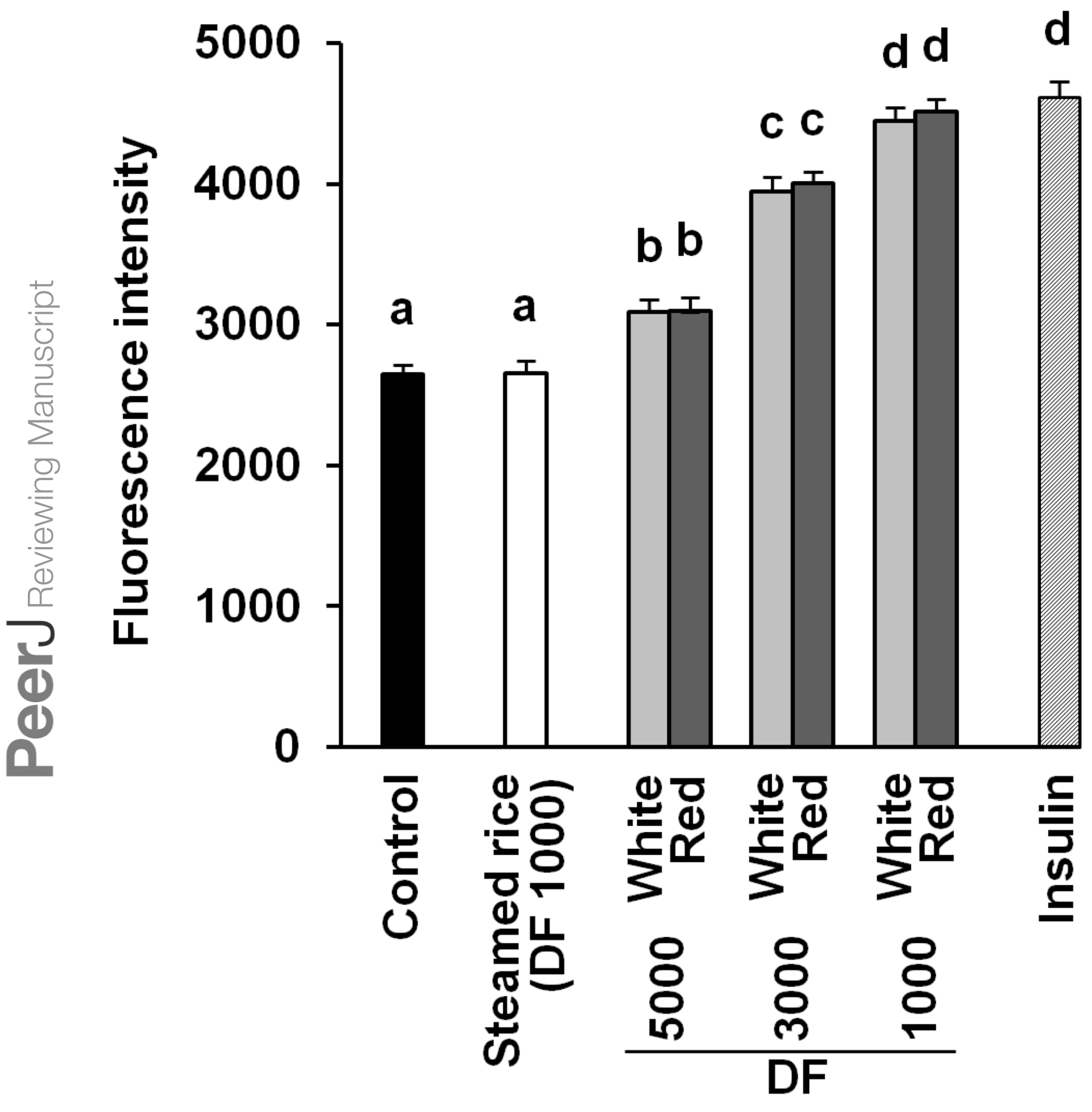




\section{Figure 3}

Glucose transporter type 4 (GLUT4) protein levels in L6 myotube cells treated with each sample extracts.

(A) Western blot analyses of GLUT4 and $\beta$-actin in L6 myotube cells. L6 myotube cells were treated for $14 \mathrm{~h}$ with steamed rice, white koji, and red koji extracts diluted at a factor of 1000 . (B) The relative signal intensities of GLUT4 to $\beta$-actin protein were measured by NIH image $J$ software. Data are expressed as means $\pm S E(n=5)$. Different letters above the bars were significantly different at $P<0.05$ by Dunnett's multiple comparison $(a, b)$. 
(A)

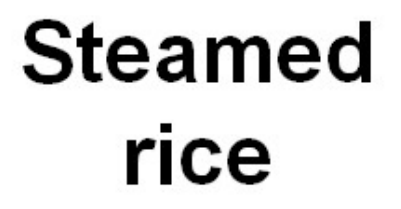

White
koji

Red

GLUT4

$\beta$-actin
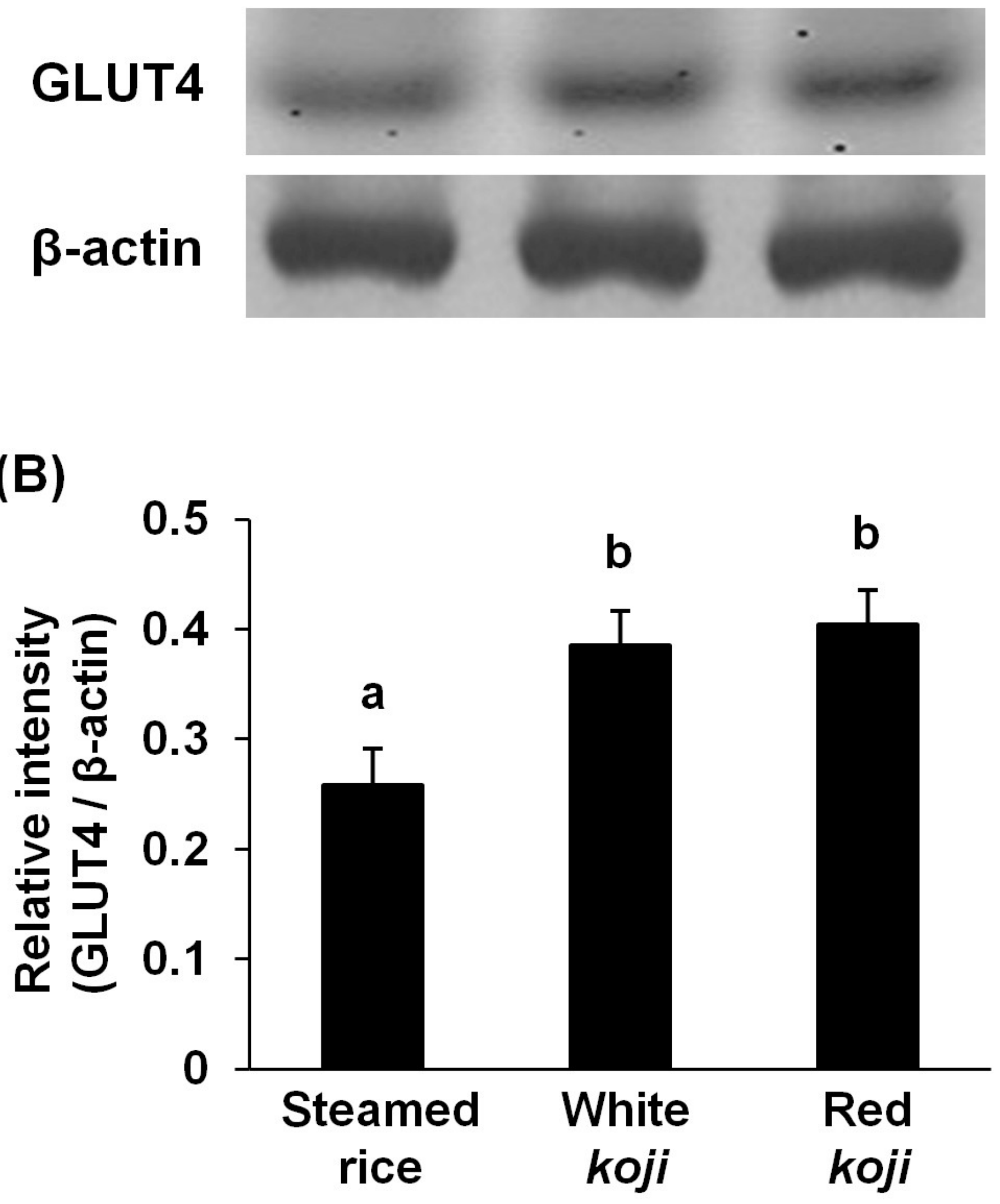


\section{Figure 4}

GLUT4 protein levels in L6 myotube cells treated with each compounds.

L6 myotube cells were treated with monacolin $\mathrm{K}$, monascin, or citrate-Na buffer ( $\mathrm{pH}$ 7.4). After $14 \mathrm{~h}$, the expression of GLUT4 and $\beta$-actin proteins was measured by western blot analysis.

The concentrations of each compound were shown as the final concentration in the medium.

The relative signal intensities of GLUT4 to $\beta$-actin protein were measured by NIH image $\mathrm{J}$ software. 

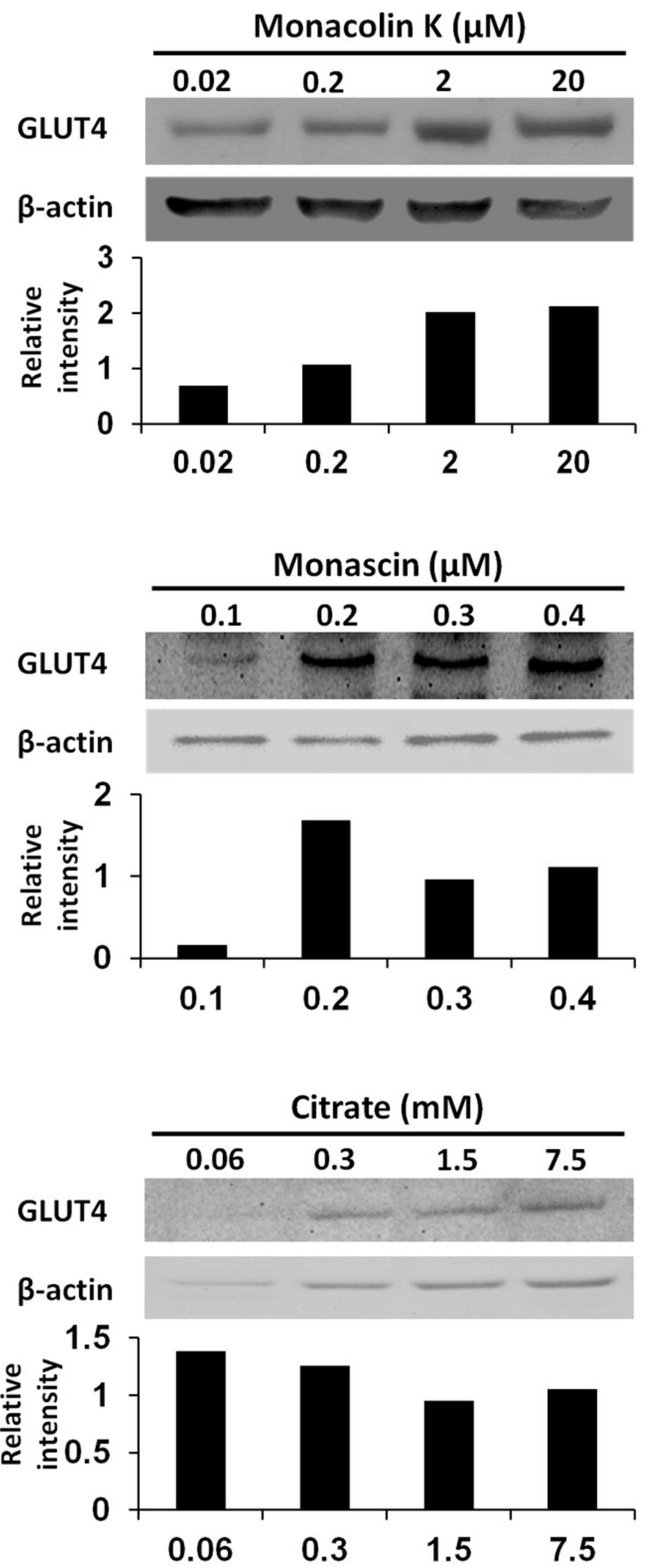